\title{
Where are the Brazilian ethnobotanical studies in the Atlantic Forest and Caatinga?
}

\author{
Heitor S.N. Liporacci ${ }^{1,4}$, Natalia Hanazaki ${ }^{1}$, Mara Rejane Ritter $^{2}$ \& Elcida de Lima Araújo ${ }^{3}$
}

\begin{abstract}
The Atlantic Forest and Caatinga ecosystems differ in terms of biodiversity and geoclimatic conditions but are similar in their rich socio-diversity and heterogeneity of vegetation types that comprise their floras. The objectives of this work were to map the ethnobotanical studies that have been conducted in these ecosystems and record the most investigated communities, regions, and vegetation formations related to this research. A literature review was made of ethnobotanical articles related to the use and knowledge of medicinal and food plants employed by local populations within the original territories of the Caatinga and Atlantic Forest. The areas with the highest concentrations of studies (Southeast and South regions in the Atlantic Forest and the states of Pernambuco and Paraíba in the Caatinga) reflect the presence of research groups in these regions. Until now, it was thought that ethnobotanical studies had been conducted throughout the Atlantic Forest and Caatinga; however, the results of this work show that both ecosystems contain areas that still need to be studied. Key words: ethnobotany, food plants, literature review, medicinal plants.

\section{Resumo}

Os ecossistemas Mata Atlântica e Caatinga apesar de diferirem em termos de biodiversidade e condições geoclimáticas se assemelham pela heterogeneidade de formações vegetais que compõem as suas floras e por serem detentores de uma rica sociodiversidade. O objetivo desta pesquisa foi de mapear as pesquisas etnobotânicas realizadas nos ecossistemas Mata Atlântica e Caatinga, chamando-se atenção para as comunidades mais investigadas, as regiões mais estudadas, assim como as formações vegetais em que se concentram maior número de pesquisas. Foi efetuada uma revisão bibliográfica sobre os artigos de cunho etnobotânico realizados em áreas pertencentes ao território original dos ecossistemas Caatinga e Mata Atlântica e que abordaram o uso ou o conhecimento de recursos vegetais medicinais e alimentícios por populações locais. As regiões com as maiores concentrações de estudos (região Sudeste e Sul na Mata Atlântica e os estados de Pernambuco e Paraíba na Caatinga), refletem a presença dos grupos de pesquisas localizados nessas regiões. As pesquisas etnobotânicas estão cumprindo o seu papel ao investigar e abranger todo o território ocupado pela Mata Atlântica e Caatinga, no entanto, diante do mapeamento realizado, percebe-se determinadas regiões em ambos os ecossistemas que ainda necessitam de um maior esforço de pesquisas.

Palavras-chave: etnobotânica, plantas alimentícias, revisão bibliográfica, plantas medicinais.
\end{abstract}

\section{Introduction}

The Atlantic Forest and Caatinga ecosystems differ in terms of biodiversity and geoclimatic conditions but are similar in their rich sociodiversity and heterogeneity of vegetation types that comprise their floras. Over the past few decades, ethnobotanical studies have documented local knowledge about the biodiversity of these ecosystems. For example, the cultural richness of the Caiçaras (Hanazaki et al. 2000; Albertasse et al. 2010), Azorean descendants (Giraldi \& Hanazaki 2010), artisanal fisherman (Fonseca-Kruel \&

\footnotetext{
${ }^{1}$ Universidade Federal de Santa Catarina - UFSC, Inst. Ciências Biológicas, Depto. Ecologia e Zoologia, Campus Universitário s/n, Córrego Grande, 88040-900 Florianópolis, SC, Brazil.

${ }^{2}$ Universidade Federal do Rio Grande do Sul - UFRGS, Inst. Biociências, Depto. Botânica, Av. Bento Gonçalves 9500, Campus do Vale, $91501-970$, Porto Alegre, RS, Brazil.

${ }^{3}$ Universidade Federal Rural de Pernambuco - UFRPE, Depto. Biologia, R. Dom Manoel de Medeiros s/n, Dois Irmãos, 52171-900, Recife, PE, Brazil.

${ }^{4}$ Author for correspondence: hliporacci@hotmail.com
} 
Peixoto 2004; Merétika et al. 2010), indigenous groups (Albuquerque et al. 2008; Cunha et al. 2012), Quilombolas (Crepaldi \& Peixoto 2010; Gomes \& Bandeira 2012), Sertanejos (Andrade et al. 2006), as well as rural (Negrelli \& Fornazzari 2007; Paulino et al. 2012) and urban (Dorigoni et al. 2001; Almeida et al. 2006) communities have been studied. In Brazil, Quilombolas are traditional people of Afro-Brazilian descent, and Sertanejos are traditional people that occupy the semiarid region, whose livelihood is usually associated with some degree of pastoralism (Diegues \& Arruda 2001).

Within the original territories of these two ecosystems, there have been several ethnobotanical studies about local communities and native plant resources from different vegetation formations, such as dense ombrophilous forest (Pinto et al. 2006), restinga (Melo et al. 2008), mixed ombrophilous forest (Althaus-Ottmann et al. 2011) and seasonal semideciduous forest (Eichemberg et al. 2009), as well as distinct vegetation formations found in the Caatinga (Albuquerque \& Andrade 2002a; Florentino et al. 2007; Roque et al. 2010).

Advances in the development of ethnobotanical studies (Oliveira et al. 2009; Liporacci et al. 2015) have led to various literature reviews. Some of these are more descriptive (Vieira \& Martins 2000; Guarim-Neto \& Morais 2003; Agra et al. 2007b; Agra et al. 2008; Oliveira et al. 2009) and others test hypotheses (Albuquerque et al. 2007; Santos et al. 2008b; Albuquerque et al. 2009; Morales \& Ladio 2009), including the application of systematic reviews and meta-analyses (Medeiros et al. 2013a; Medeiros et al. 2013b). In addition, some of these review studies use different levels of approach, for example, the national (Ritter et al. 2015), regional (Agra et al. 2007b) or state level (Guarim-Neto \& Morais 2003; Silva \& Albuquerque 2005).

For Brazil, although ethnobotanical research has grown and contributed to the systematization of local knowledge associated with biodiversity, there has been little effort to map the distribution of studies about plant use to show where there has been a concentration of studies verses little or no research. Due to the importance of these review articles, the objectives of this work were to map the ethnobotanical studies that have been conducted in the Atlantic Forest and Caatinga ecosystems and record the most investigated communities, regions, and vegetation formations related to this research. These two ecosystems were chosen because they include regions where there are the most research groups that conduct ethnobotanical studies.

\section{Materials and Methods}

General characterization of the study area

The Atlantic Forest extends more than 3,300 km along coastal Brazil, covering 17 states from Rio Grande do Sul to the Northeast Region: Espírito Santo (100\%), Santa Catarina (99.91\%), Rio de Janeiro (98.59), Paraná (96.65\%), São Paulo (79.51\%), Alagoas (52.01\%), Minas Gerais (47.81\%), Rio Grande do Sul (46.82\%), Sergipe (32.45\%), Bahia (31.36\%), Pernambuco (18\%), Mato Grosso do Sul (14.39\%), Paraíba (11.92\%), Piauí (9.08\%, Rio Grande do Norte (6.19\%), Ceará (3.33\%), and Goiás (3.13\%) (CN-RBMA, 2013). Originally, this forest occupied 1,481,946 $\mathrm{km}^{2}$, which is equivalent to $17.4 \%$ of the country (Metzger 2009). Today, most of the Atlantic Forest is gone or has been modified by humans. In 1992, the Atlantic Domain and associated ecosystems were legally recognized by the National Environmental Council (Conselho Nacional do Meio Ambiente or CONAMA) in Decree $n^{\circ} 6.600 / 2008$ and Law 11.428/2006 (law of the Atlantic Forest), which were subsequently consolidated in Decree $\mathrm{n}^{\circ}$ 6.660/2008 and the Map of the Area of Application in Law 11.428/2006. Variations in elevation and differences in soil and relief occur in the area occupied by the Atlantic Forest, and this has resulted in the heterogeneity of phytophysiognomies found in this region, for example, dense ombrophilous forest, mixed ombrophilous forest, open ombrophilous forest, seasonal semideciduous forest, seasonal deciduous forest, disjunctions of forest formations and swamps within other biomes, high altitude grasslands, pioneer formations (restinga, mangrove, saline fields, lakeside and riverside communities), vegetation refuges, disjunctions of steppe savanna and steppe, areas of ecological tension, and oceanic and coastal islands (MMA 2010).

The Caatinga, unlike many other vegetation formations, is found only in Brazil, occupies an area of $844,453 \mathrm{~km}^{2}$ (MMA 2012), and occurs in the states of Ceará $(100 \%)$, Rio Grande do Norte (95\%), Paraíba (92\%), Pernambuco (83\%), Piauí (63\%), Bahia (54\%), Sergipe (49\%), Alagoas (48\%), Maranhão (34\%), Tocantins (9\%) and Minas Gerais (2\%) (IBGE 2012; MMA 2012). According to the Ministry of the Environment (2011), the Caatinga occupies $60 \%$ of the states of the Northeast Region and $13 \%$ of the country. Variations in elevation, soil, relief, and precipitation create heterogeneity in the vegetative physiognomy of this 
ecosystem. However, unlike the Atlantic Forest, the classification of different vegetation subtypes in the Caatinga is still somewhat indefinite. According to Giullietti et al. (2004), given the diversity of vegetation patterns found in the Caatinga, it is still not possible to define an ideal classification system for these formations. Despite this issue, most studies conducted in the Caatinga recognize and use at least four types, shrubby/woody (predominant type), shrubby caatinga, woody caatinga and park caatinga, which was the classification adopted for the present study.

\section{Literature review and}

\section{selection of articles}

A literature review was conducted of ethnobotanical studies from areas within the original territories of the Caatinga and Atlantic Forest ecosystems that investigated the use or knowledge of medicinal and/or food plants employed by local populations. Only scientific articles that were published in national and international journals were included. Organization and selection of articles were made in two stages. The first stage involved the construction of a database using two principle search portals for scientific literature (Web of Science and Scopus). For both portals, searching was standardized by using the keywords "Ethnobotany + Brazil." The only peculiarity of each portal was in relation to the search fields. In Scopus the keyword "Ethnobotany" was used in the field "ALL TOPICS" and "Brazil" in the field "TITLE-ABS-KEY," and in the Web of Science "Ethnobotan*" in the field "Topics" and "Brazil*" in the field "Topics." In both portals, searches were made for articles published until the end of 2014. The articles recovered from each search were analyzed and those that were not made in the study areas were excluded.

In the second stage, websites of Brazilian journals that publish ethnobotanical studies were searched, including the following: 1) Revista Brasileira de Plantas Medicinais; 2) Revista Brasileira de Farmacognosia; 3) Acta Botanica Brasilica; 4) Rodriguésia; 5) Revista Biotemas; 6) Revista Brasileira de Biociências; 7) Acta Scientiarum (Jornal específico de Ciências Biológicas e Ciências da Saúde); 8) Anais da Academia Brasileira de Ciências; 9) Revista Brasileira de Farmácia; 10) Bio Terra - Revista de Biologia e Ciência da Terra; 11) Revista Saúde e Ambiente; 12) Revista Caatinga; 13) Neotropical Biology and Consevation; 14) Iheringia - Série Botânica; 15) Ethnobiology and Conservation;
16) Sitientibus - Série Ciências Biológicas; 17) Revista Fitos; 18) Revista Acadêmica de Ciências Agrárias Ambientais; 19) Revista Vértices; 20) Revista Científica Eletrônica de Engenharia Florestal; 21) Revista de Estudos Ambientais; 22) Revista Semina; 23) Boletim do Museu de Biologia Mello Leitão; 24) Bioscience Journal; 25) Revista de Ciências Farmacêuticas Básica e Aplicada; 26) Unoesc \& Ciência - ACBS; 27) Interações Revista Internacional de Desenvolvimento Local; 28) Revista Brasileira de Agroecologia; 29) Revista Biodiversidade; 30) Revista Árvore; 31) Boletim do Museu Paraense Emílio Goeldi - Ciências Humanas; 32) Revista Floresta e Ambiente; and 33) Revista Geografar. The search was made using the website for each journal and included all the articles available from the first volume of the journal to the last volume of 2014. To find additional articles the literature cited in articles selected was reviewed for publications covering the study topic. If a new article was found, the literature cited in the publication was also reviewed.

\section{Selection of articles:}

adopted criteria

For the articles included in the study, the following criteria were used: 1) study area located completely (or predominantly) within the original area of the Atlantic Forest or Caatinga; 2) study focus about the knowledge and/or use of medicinal and food plants by local communities, including works exclusively about medicinal or food plants, those that included both categories and those that covered many categories, including medicinal and food plants; 3) study used methods characteristic of ethnobotanical research (mainly interviews); and 4) study was published before 2015 .

Studies conducted in transition areas (Atlantic Forest/Pampa, Atlantic Forest/Cerrado, Caatinga/ Cerrado) were not included, except when the study site was confirmed to be within the original area of Atlantic Forest or Caatinga (even when the study region was on the border of other vegetation types), such as Macedo et al. (2007) and Eichemberg et al. (2009).

Studies related to selling plants in fairs and public markets were also excluded because they did not reference the location of where all of the plants were obtained. In addition, studies were excluded if they only used common names of species, were literature reviews or were checklists or floristic surveys that did not cover what is known about the use of local or traditional plants. 
Classification of the Phytophysiognomies and mapping the reviewed studies

Defining the phytophysiognomy for each study area was based on information provided in the article. If this was not mentioned by the authors it was inferred using maps and by consulting specialists. For the Atlantic Forest phytophysiognomy, the Atlas dos Remanescentes Florestais da Mata Atlântica was used (SOS Mata Atlântica/INPE 2015) following the classification of the domain and associated ecosystems in Law $\mathrm{n}^{\circ} 11.428$ (2006). There are no detailed maps of the the Caatinga so classifying this phytophysiognomy was based on municipality, as done by Araújo et al. (2007). If a study was conducted in Carrasco, a xerophytic vegetation in the Northeast Region of Brazil (Andrade-Lima 1978), it was recorded as occurring in the Caatinga.

Mapping the study areas based on the publications was done in QGIS 2.8.1 ${ }^{\circledR}$. When the coordinates of the municipalities were not mentioned in the articles they were obtained using the website (<http://www.apolo11.com $>$ ) and converted from degree/minute/second to decimal degrees using the website $(<\mathrm{http}$ ://www. dpi.inpe.br/calcula/ $>$ ). The converted data was then imported into a Microsoft EXCEL ${ }^{\circledR} 2010$ spreadsheet and saved in CSV format.

\section{Results and Discussion}

Reviewed articles and

\section{local communities}

The literature search resulted in 173 scientific articles. In relation to the biomes, 112 articles were studies made within the original area of the Atlantic Forest (Tab. 1 in supplementary material <https://figshare.com/s/ a48efa9b2e384a902a7d> - DOI: 10.6084/ $\mathrm{m} 9$.figshare.5327596), 63 articles were of studies made within the original area of the Caatinga (Tab. 2 in supplementary material $<$ https://figshare. com/s/8250192e6a27eaed9010> - DOI: 10.6084/ $\mathrm{m} 9$.figshare.5327599) and 4 studies were from transition zones between the Atlantic Forest and Caatinga (Tab. 3 in supplementary material $<$ https://figshare.com/s/c280b515507b205837f7> - DOI: 10.6084/m9.figshare.5327602).

Based on the compiled studies, the local communities in the Atlantic Forest and Caatinga contain great cultural diversity (Fig. 1a,b). A higher number of works were made in non-urban areas (areas not located within the perimeters of cities) in both the Atlantic Forest and Caatinga; however, ethnobotanical studies within cities are becoming more common (Fig. 2a,b).

Pilla et al. (2006) and Costa \& Mayworm (2011) emphasized the broad scope of ethnobotanical studies in different types of communities, which were mainly conducted in rural and urban areas. A high frequency of studies in rural areas was also noted by Ritter $e t$ al. (2015), who conducted a study at the national level of ethnobotanical research made between 1988 and 2013. The number of ethnobotanical studies made in urban communities, mainly in the Atlantic Forest, is due to many factors, such as decrease in vegetation cover, widespread real estate speculation and rampant urban growth (MMA 2010). According to IBGE (2010), 84\% of the Brazilian population lives in urban areas. In addition, over the last few decades, ethnobotanical studies focused on conservation of biodiversity in home gardens (Pulido et al. 2008; Eichemberg et al. 2009) have contributed to an increase in studies in urban areas because these gardens generally have many ex situ cultivated, native and exotic species (Costa \& Mayworm 2011). Ritter et al. (2015) also note the high number of immigrants in Brazilian cities as fundamental to understanding the introduction of medicinal species into the Brazilian pharmacopeia.

For the Atlantic Forest, some important studies have been made in coastal communities (such as the Caiçaras, Azorian descendants and artisanal fisherman), which were mostly conducted by research centers in the Southeast and South regions. In addition, the high number of studies of rural communities in the Caatinga is because of research centers in the Northeast Region that are predominantly in rural communities; although, these research centers also study communities in northeastern Atlantic Forest (Ritter et al. 2015).

Despite the indigenous cultural diversity in Brazil, and considering the last IBGE census recorded 817,963 indigenous people in 305 ethnic groups (IBGE 2010), it is worth noting the low representativeness of published studies about indigenous peoples from the Atlantic Forest and Caatinga. According to Coutinho (2002), as of 2002 the ethnobotany of less than one third of the indigenous cultures in Brazil had been completely studied. After fourteen years the situation has not changed, which can be seen in the review by Ritter et al. (2015) that included all 

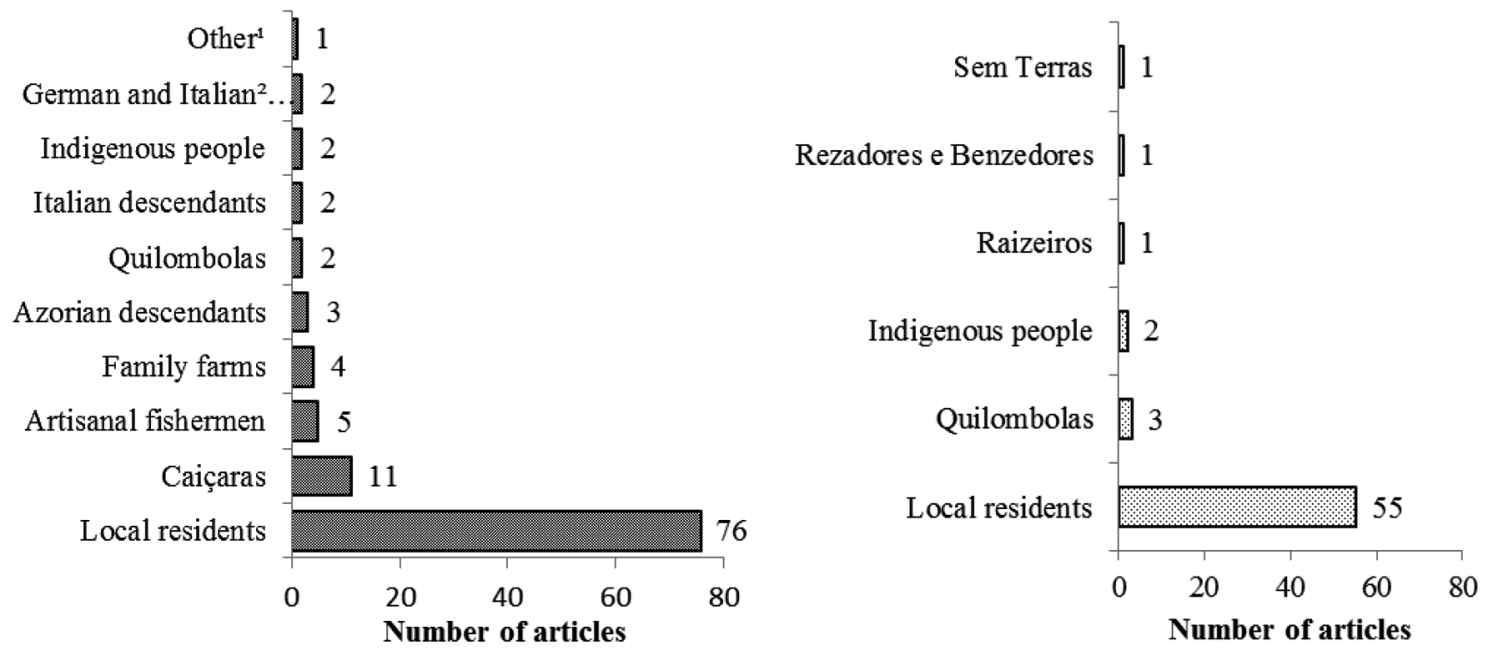

Figure 1 - a. communities involved in ethnobotanical studies in areas of the Atlantic Forest. $\left[{ }^{1}=\right.$ Other communities: Sitiantes (1), Woodsman (1), Two communities in the same article (1), Pais e Mães de Santo (1), Producers (1); ${ }^{2}=$ German and Italian descendants $(\mathrm{N}=112)]$. b. communities involved in ethnobotanical studies in areas of the Caatinga $(\mathrm{N}=63)$.

of the biomes in Brazil and recorded few articles about indigenous groups. According to Haverroth (2010), in Amazonia this scenario has also been observed and may reflect the lack of specialists in the region as well as laws that restrict access to genetic resources and associated traditional knowledge. Another factor that could be attributed to this is the time it takes to complete studies about indigenous groups, especially considering the large amount of legal bureaucracy involved and the significant amount of time needed for the researcher/indigenous person to build a working relationship, which is often incompatible with the

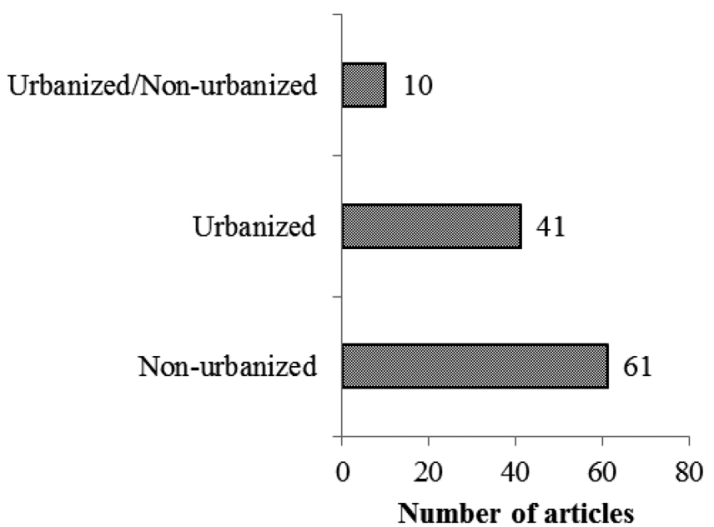

time given to complete a master's or $\mathrm{PhD}$ degree (Liporacci et al. 2015; Pedrollo \& Kinupp 2015).

It is also important to note the works that did not define the cultural groups, including $71(66.35 \%)$ from the Atlantic Forest and 36 (55.38\%) from the Caatinga, which are classified in the present study as "local residents". The same results were found by Ritter et al. (2015), where 143 articles (55.4\%) involved one particular social group. According to the same authors, this may be a reflection of the difficulties of defining specific ethnic groups in Brazil, especially because of the high cultural diversity in the country.

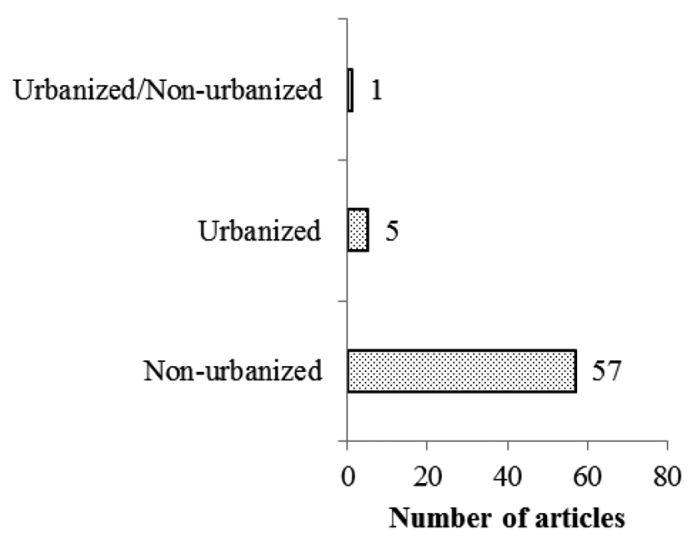

Figure 2 - a. urbanization of the communities involved in ethnobotanical studies made in areas of the Atlantic Forest $(\mathrm{N}=112)$. b. urbanization of the communities involved in ethnobotanical studies in areas of the Caatinga $(\mathrm{N}=63)$. 
Representativeness of studies

by state and region

For the Atlantic Forest, ethnobotanical articles were found that involved medicinal and food plants from the following 12 states: Santa Catarina (20 articles), Rio de Janeiro (16), São Paulo (16), Bahia (13), Minas Gerais (12), Rio Grande do Sul (9), Paraná (9), Pernambuco (7), Espírito Santo (3), Paraíba (3), Sergipe (2), Rio Grande do Norte (1) and more than one state (1). The only study that exclusively involved food plants was made in the Vale do Paraíba in the state of São Paulo (Pilla \& Amorozo 2009). At a regional scale, most of the works are from the Southeast Region (47 articles), followed by the South (38) and Northeast regions (25). There were no ethnobotanical studies for five of the 17 states with Atlantic Forest (Mato Grosso do Sul, Goiás, Ceará, Piauí, Alagoas). However, the representativeness of the Atlantic Forest biome in these states is small compared to the states that are completely within the biome, such as Santa Catarina, Paraná, Rio de Janeiro and Espírito Santo. Another reason for the concentration of ethnobotanical studies and publications is that most of the ethnobotany research groups are in these states.

For the Caatinga biome, which is found in 11 states, articles of studies from the following eight states were found: Pernambuco (22 articles), Paraíba (18), Bahia (7), Rio Grande do Norte (7), Piauí (3), Ceará (2), Alagoas (1), Sergipe (1), Pernambuco/Paraíba (1) and Ceará/Pernambuco (1). The only work found that exclusively studied food plants in the Caatinga was about two rural communities, one in Pernambuco and the other in Paraíba (Nascimento et al. 2012). No publications were found of studies from Tocantins, Maranhão and Minas Gerais. In addition, Ceará occurs almost completely within the Caatinga biome but there are few ethnobotanical studies from this state. Tocantins, Maranhão and Minas Gerais contain the lowest proportion of Caatinga biome compared to the other northeastern states, which is a possible reason for the lack of published articles from these areas. The concentration of ethnobotany research groups in Pernambuco and Paraíba could be the main reason why these two states have the highest number of publications.

In the territory originally occupied by Atlantic Forest, the majority of the studies are from coastal regions (Fig. 3), which is evidence that there is a predominance of studies near the capitals. Studies have also been conducted in inland regions; however, for states with Atlantic Forest, most of the interior regions that have communities with people with knowledge about medicinal and food plants are poorly studied. In addition, few ethnobotanical studies have been conducted in the northeastern portion of the Atlantic Forest (Silva \& Andrade 2005).

There was a similar concentration of studies for the the original area occupied by the Caatinga (Fig. 3). Many studies have been conducted in rural areas of the Northeast Region, with gaps in the north, south and central parts of Bahia, all of Ceará, western Pernambuco and most of Piauí; these are potentially good places for new studies. Considering the Atlantic Forest and Caatinga are ecosystems with high biodiversity and anthropic activity, it is extremely important that future research is conducted in unstudied areas. The present review of the entire area occupied by these biomes can help determine these regions and will help in the collection and analysis of data about food and medicinal resources used by local communities. In addition, based on the gaps found in the present study, more research about food plants is needed.

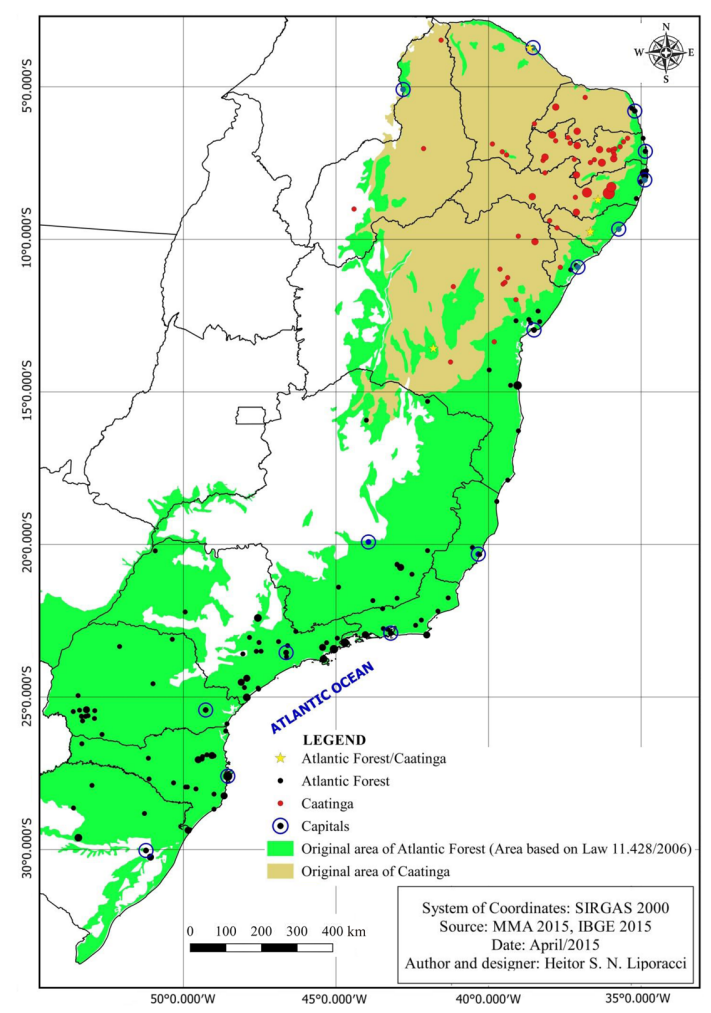

Figure 3 - Geographic distribution of published articles about use and knowledge of plants for food and medicine in Atlantic Forest and Caatinga. 
Representativeness of studies

by phytophysiognomy

In relation to the original area of Atlantic Forest, the majority of the studies were conducted in dense ombrophilous forest (Fig. 4a). For the Caatinga, most studies were made in shrub/woody caatinga (Fig. 4b).

According to the National Council of the Atlantic Forest Biosphere Reserve (Conselho Nacional da Reserva da Biosfera da Mata Atlântica 2013), within the Atlantic Forest, the largest formation is seasonal forest $\left(635,552 \mathrm{~km}^{2}\right.$ or $48.65 \%$ ) and the second largest formation is ombrophilous forest $\left(406,446 \mathrm{~km}^{2}\right.$ or $\left.31.11 \%\right)$, which has three phytophysiognomy subtypes (dense ombrophilous forest, mixed ombrophilous forest and open ombrophilous forest). The same source notes that the Atlantic Forest domain was originally $1,306,421 \mathrm{~km}^{2}$.

The large areas these phytophysiognomies occupy partially explain the high number of studies made in ombrophilous formations. This is supported by the predominance of studies
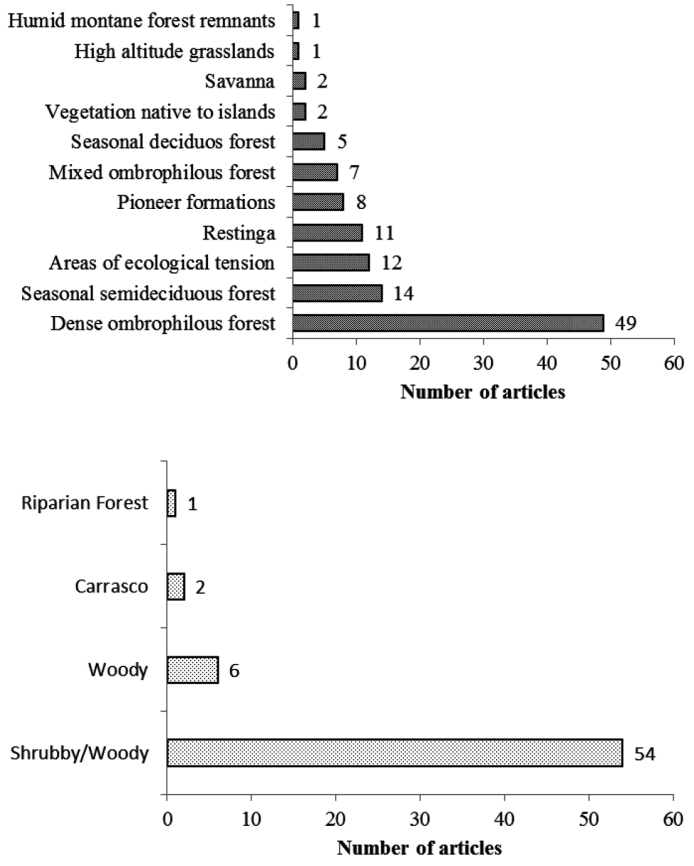

Figure 4 - a. number of studies made in the diverse phytophysiognomies that comprise the Atlantic Forest biome $(\mathrm{N}=112)$. b. number of studies made in the diverse phytophysiognomies that comprise the Caatinga biome $(\mathrm{N}=63)$. conducted in dense ombrophilous forest, which is found in 11 of the 17 states with Atlantic Forest. Another reason for the high number of studies is related to the history of the coastal region (where these formations are more concentrated), which was the first area to be cleared and inhabited by humans (Thomaz \& Monteiro 1997). Besides containing the largest cities and number of people, traditional communities are found in this area, such as the Caiçaras, fisherman and Azorian descendants (CN-RBMA 2013). Research centers that study ethnobotany are also present in these phytophysiognomies. In addition, although the seasonal forest formation is larger, it contained fewer studies compared to ombrophilous forest.

In relation to the Caatinga, the studies were made predominantly in areas with shrubby/woody caatinga. Unlike the studies in Atlantic Forest, the ethnobotany studies made in Caatinga did not cite the vegetation type. However, shrubby/woody Caatinga is the predominant type in this ecosystem so we assumed that most of the studies were made in areas with this phytophysiognomy.

It is important to note that the present work considered studies that were made in areas within the original territories of the Atlantic Forest and Caatinga, which existed before human exploration. Today, these ecosystems have been heavily impacted by humans and there are few untouched natural areas. Due to large scale industry, the exploration of fossil fuels and globalization, more than three quarters of the the land on Earth has been transformed into anthropogenic biomes (anthromes) (Ellis 2015). Humans live in the era of the Anthropocene and some of the consequences of this period are the alteration of species richness of native vegetation and an increase in the introduction of exotic species (Ellis 2012). Thus, when referring to biomes and global ecosystems it is necessary to disconnect from the idea of pristine ecosystems.

\section{Conclusion}

In Brazil, the socio-biodiversity of the Caatinga and Atlantic Forest ecosystems has contributed over time to the advancement of ethnobotanical studies related to medicinal and food plants. There has been an increase in focusing on non-urban communities (rural communities) in both the Caatinga and Atlantic Forest. However, studies in urban areas, such as large cities, have also contributed to new aspects of ethnobotanical research. 
The regions with the highest concentrations of research (Southeast and South regions for the Atlantic Forest and the states of Pernambuco and Paraíba for the Caatinga) reflect the presence of research groups in these areas that conducted these studies and have accumulated a lot of ethnobotanical knowledge, especially about medicinal plants. Although the Atlantic Forest and Caatinga contain heterogeneous vegetation formations and the ethnobotanical studies conducted in them are concentrated in certain areas, in general this research is playing a role in investigating the entirety of these important Brazilian ecosystems. Nevertheless, mapping these studies shows there are regions in both the Atlantic Forest and Caatinga that still need to be studied.

Considering the vast area that these ecosystems cover and the socio-biodiversity of Brazil, there is no doubt that there is still much to be explored in this field, mainly in relation to ethnobotanical knowledge of Brazilian indigenous peoples that have not been studied.

The map made in this work will help with planning future studies by allowing researchers to select new areas for ethnobotanical investigations and by stimulating discussions related to this area of science. In turn, this will increase the knowledge about native species from different vegetation formations that comprise the ecosystems of Brazil.

\section{Acknowledgments}

This paper is contribution number 17 supported by CAPES/PNADB through the project "Knowledge, use and conservation of plant biodiversity in Atlantic Forest and Caatinga" (UFSC/UFRPE/UFRGS). N. Hanazaki and E.L. Araújo thank CNPq for the productivity grants (306478/2012-9 - 309613/2015-9 and $302645 / 2014-4$, respectively).

\section{References}

Abreu DBO, Oliveira-Filho RB, Vasconcelos-Neto CFA, Lucena CM, Felix LP \& Lucena RFP (2011) Classificação etnobotânica por uma comunidade rural em um brejo de altitude no Nordeste do Brasil. Revista de Biologia e Farmácia 6: 55-74.

Agra MF, Baracho GS, Nurit K, Basilio IJLD \& Coelho VPM (2007a) Medicinal and poisonous diversity of the flora of "Cariri Paraibano", Brazil. Revista Brasileira de Farmacognosia 111: 383-395.

Agra MF, Freitas PF, Freitas PF \& Barbosa-Filho JM (2007b) Synopsis of the plants known as medicinal and poisonous in Northeast of Brazil. Revista Brasileira de Farmacognosia 17: 114-140.
Agra MF, Silva KN, Basílio IJLD, Freitas PF \& BarbosaFilho JM (2008) Survey of medicinal plants used in the region Northeast of Brazil. Revista Brasileira de Farmacognosia 18: 472-508.

Albertasse PD, Thomaz LD \& Andrade MA (2010) Plantas medicinais e seus usos na comunidade da Barra do Jucu, Vila Velha, ES. Revista Brasileira de Plantas Medicinais Botucatu 12: 250-60.

Albuquerque UP \& Andrade LHC (2002a) Conhecimento botânico tradicional e conservação em uma área de caatinga no estado de Pernambuco, Nordeste do Brasil. Acta Botanica Brasilica 16: 273-85.

Albuquerque UP \& Andrade LHC (2002b) Uso de recursos vegetais da Caatinga: o caso do agreste do estado de Pernambuco (Nordeste do Brasil). Interciências 27: 336-46.

Albuquerque UP, Andrade LHC \& Silva ACO (2005a) Use of plant resources in a seasonal dry forest (Northeastern Brazil). Acta Botanica Brasilica 19: 27-38.

Albuquerque UP, Andrade LHC \& Caballero J (2005b) Structure and floristics of homegardens in Northeastern Brazil. Journal of Arid Environments 62: 491-506.

Albuquerque UP (2006) Re-examining hypotheses concerning the use and knowledge of medicinal plants: a study in the Caatinga vegetation of NE Brazil. Journal of Ethnobiology and Ethnomedicine 2: 1-10.

Albuquerque UP, Medeiros PM, Almeida ALS, Monteiro JM, Lins-Neto EMF, Melo JG, Melo JG \& Santos JP (2007) Medicinal plants of the caatinga (semi-arid) vegetation of NE Brazil: a quantitative approach. Journal of Ethnopharmacology 114: 325-354.

Albuquerque UP, Silva VA, Cabral MC, Alencar NL \& Andrade LHC (2008) Comparisons between the use of medicinal plants inindigenous and rural Rural Caatinga (Dryland) communities in NE Brazil. Boletim Latinoamericano y del Caribe de Plantas Medicinales y Aromáticas 7: 156-170.

Albuquerque UP, Araujo TAS, Ramos MA, Nascimento VT, Lucena RFP, Monteiro JM, Alencar NL \& Araujo EL (2009) How ethnobotany can aid biodiversity conservation: reflections on investigations in the semiarid region of NE Brazil. Biodiversity and Conservation 18: 127-150.

Albuquerque UP, Soldati GT, Sieber SS, Medeiros PM, Sa JC \& Souza LC (2011) Rapid ethnobotanical diagnosis of the Fulni-o^ Indigenous lands (NE Brazil): floristic survey and local conservation priorities for medicinal plants. Environment Development and Sustainability 13: 277-292.

Alencar NL, Ferreira-Júnior WSF \& Albuquerque UP (2014) Medicinal Plant Knowledge Richness and Sharing in Northeastern Brazil. Economic Botany 68: 371-382.

Almeida CFCBR, Amorim ELC, Albuquerque UP \& Maia MB (2006) Medicinal plants popularly 
used in the Xingó region - a semi-arid location in Northeastern Brazil. Journal of Ethnobiology and Ethnomedicine 2: 1-7.

Almeida NFL, Silva SRS, Souza JM, Queiroz APN, Miranda GS \& Oliveira HB (2009). Levantamento etnobotânico de plantas medicinais na cidade de Viçosa - MG. Revista Brasileira de Farmacognosia 90: 316-320.

Almeida VS \& Bandeira FPS (2010) O significado cultural do uso de plantas da caatinga pelos quilombolas do Raso da Catarina, município de Jeremoabo, Bahia, Brasil. Rodriguésia 61: 195-209.

Almeida CFCBR, Ramos MA, Silva RRV, Melo JG. \& Medeiros MFT (2012) Intracultural variation in the knowledge of medicinal plants in an urban-rural community in the Atlantic Forest from Northeastern Brazil. Journal Evidence-Based Complementary and Alternative Medicine 1-15.

Almeida MZ, Leda PHO, Silva MQOR, Pinto A, Lisboa M, Guedes MLML \& Peixoto AL (2014) Species with medicinal and mystical-religious uses in São Francisco do Conde, Bahia, Brazil: a contribution to the selection of species for introduction into the local Unified Health System. Revista Brasileira de Farmacognosia 24: 171-184.

Althaus-Ottmann MM, Cruz MJR \& Fonte NN (2011) Diversidade e uso das plantas cultivadas nos quintais do Bairro Fanny, Curitiba, PR, Brasil. Revista Brasileira de Biociências 9: 39-49.

Alves CM, Lucena CM, Santos SS, Lucena RFP \& Trovão DMB (2014) Ethnobotanical study of useful vegetal species in two rural communities in the semi-arid region of Paraíba state (Northeastern Brazil). Boletim do Museu de Biologia Mello Leitão 34: 75-96.

Andrade-Lima D (1978) Vegetação. In: Lins RC (ed.) Bacia do Parnaíba: Aspectos fisiográficos. Instituto Joaquim Nabuco de Pesquisas Sociais, Recife. Pp. 131-135.

Andrade CTS, Marques JGW \& Zappi DC (2006) Utilização medicinal de cactáceas por sertanejos baianos. Revista Brasileira de Plantas Medicinais 8: $36-42$.

Andrade SEO, Maracajá PB, Silva RA, Freires GF \& Pereira AM (2012) Estudo etnobotânico de plantas medicinais na comunidade Várzea Comprida dos Oliveiras, Pombal, Paraíba, Brasil. Revista Verde de Agroecologia e Desenvolvolvimento Sustentável 7: 46-52.

Apollo 11 (2015) Coordenadas geográficas. Available at $<$ http://www.apolo11.com/latlon.php $>$. Access on 20 December 2015.

Araujo EL, Castro CC \& Albuquerque UP (2007) Dynamics of brazilian Caatinga: a review concerning the plants, environment and people. Function Ecosystem Commun 1: 15-28.

Baldauf C et al. (2009) "Ferveu, queimou o ser da erva": conhecimentos de especialistas locais sobre plantas medicinais na região Sul do Brasil. Revista Brasileira de Plantas Medicinais 11: 282-291.

Baptista MM, Ramos MA, Albuquerque UP, Coelho-deSouza G \& Ritter MR (2013) Traditional botanical knowledge of artesanal fishers in southern Brazil. Journal of Ethnobiology and Ethnomedicine 9: 2-16.

Baptistel AC, Coutinho JMCP, Lins-Neto EMF \& Monteiro JM (2014) Plantas medicinais utilizadas na comunidade Santo Antônio, Currais, Sul do Piauí: um enfoque etnobotânico. Revista Brasileira de Plantas Medicinais 16: 406-425.

Barrella W, Breier TB \& Leme GA (2010) Levantamento etnobotânico do uso popular de plantas medicinais por comunidades rurais atendidas pela UBSF, Jundiaquara, Araçoiaba da Serra, SP. Revista Eletronônica de Biologia 3: 89-105.

Barroso RM, Reis A \& Hanazaki N (2010) Etnoecologia e etnobotânica da palmeira juçara (Euterpe edulis Martius) em comunidades quilombolas do Vale do Ribeira, São Paulo. Acta Botanica Brasilica 24: 518-528.

Battisti C, Garlet TMB, Essi L, HorbachI RK, Andrade A \& Badke R (2013) Plantas medicinais utilizadas no município de Palmeira das Missões, RS, Brasil. Revista Brasileira de Biociências 11: 338-348.

Begossi A, Leitao-Filho HE \& Richerson PI (1993) Plant uses in a brazilian coastal fishing community (buzios island). Journal of Ethnobiology 13: 233-256.

Begossi A, Hanazaki N \& Tamashiro JY (2002) Medicinal plants in the atlantic forest (Brazil): knowledge, use and conservation. Human Ecology 30: 281-299.

Borges NK \& Bautista HP (2010) Etnobotânica de plantas medicinais na comunidade de Cordoaria, litoral norte do estado da Bahia, Brasil. Plurais 1: 153-174.

Borges R \& Peixoto AL (2009) Conhecimento e uso de plantas em uma comunidade caiçara do litoral sul do estado do Rio de Janeiro, Brasil. Acta Botanica Brasilica 23: 769-779.

Boscolo OH \& Senna-Valle L (2008) Plantas de uso medicinal em Quissamã, Rio de Janeiro, Brasil. Iheringia Série Botânica 63: 263-277.

Botrel RT, Rodrigues LA, Gomes LJ, Carvalho DA \& Fontes MAL (2006) Uso da vegetação nativa pela população local no município de Ingaí, MG, Brasil. Acta Botanica Brasilica 20: 143-156.

Brito MR \& Senna-Valle L (2011) Plantas medicinais utilizadas na comunidade caiçara da Praia do Sono, Paraty, Rio de Janeiro, Brasil. Acta Botanica Brasilica 25: 363-372.

Brito MR \& Senna-Valle L (2012) Diversity of plant knowledge in a "Caiçara" community from the Brazilian Atlantic Forest coastal. Acta Botanica Brasilica 26: 735-747.

Calculadora Geográfica. (2015) Available at $<$ http://www. dpi.inpe.br/calcula/>. Access on 20 December 2015.

Carvalho TKN, Souza RF, Meneses SSS, Ribeiro JPO, Felix LP \& Lucena RFP (2012) Plantas usadas por 
uma comunidade rural na depressão sertaneja no Nordeste do Brasil. Revista de Biologia e Farmácia, Volume especial: 92-120.

Castro JA, Brasileiro BP, Lyra DH, Pereira DA, Chaves JL \& Amaral CLF (2011) Ethnobotanical study of traditional uses of medicinal plants: the flora of caatinga in the community of Cravolândia-BA, Brazil. Journal of Medicinal Plants Research 5: 1905-1917.

Chaves EMF \& Barros RFM (2012) Diversidade e uso de recursos medicinais do carrasco na APA da Serra da Ibiapaba, Piauí, Nordeste do Brasil. Revista Brasileira de Plantas Medicinais 14: 476-486.

Christo AG, Bruni RRG \& Kruel VSF (2006) Uso de recursos vegetais em comunidades rurais limítrofes à reserva Biológica de Poço das Antas, Silva Jardim, Rio de Janeiro: estudo de caso na Gleba Aldeia Velha. Rodriguésia 57: 519-542.

Christo AG, Bruni RRG \& Silva AG (2010) Local knowledge on medicinal plant gardens in a rural community near the Atlantic Rain Forest, southeastern Brazil. Revista Brasileira de Farmacognosia 20: 494-501.

Conde BE, Siqueira AM, Rogerio ITS, Marques JS, Borcada GG, Ferreira MQ, Chedier LM \& Pimenta DS (2014) Synergy in ethnopharmacological data collection methods employed for communities adjacent to urban forest. Revista Brasileira de Farmacognosia 24: 425-432.

Conselho Nacional da Reserva da Biosfera da Mata Atlântica. (2013) Ecossistemas. Apresenta informações sobre as fitofisionomias da Mata Atlântica. Available at <http://www.rbma.org.br/ default 02.asp>. Access on 13 April 2013.

Cordeiro JMP \& Félix LP (2014) Conhecimento botânico medicinal sobre espécies vegetais nativas da caatinga e plantas espontâneas no agreste da Paraíba, Brasil. Revista Brasileira de Plantas Medicinais 16: 685-692.

Costa-Neto EM \& Oliveira MVM (2000) The use of medicinal plants in the country of Tanquinho, state of Bahia, North-eastern Brazil. Revista Brasileira de Plantas Medicinais 2: 1-8.

Costa LCB, Rocha EA, Silva LAM, Jardim JG, Silva DC, Gaião LO \& Moreira RCT (2006) Levantamento preliminar das espécies vegetais com potencial econômico no Parque Municipal da Boa Esperança, Ilhéus, Bahia, Brasil. Acta Farmaceutica Bonaerense 25: 184-91.

Costa VP \& Mayworm MAS (2011) Plantas medicinais utilizadas pela comunidade do bairro dos tenentes município de Extrema, MG, Brasil. Revista Brasileira de Plantas Medicinais 13: 282-292.

Coutinho DF, Travassos LMA \& Amaral FMM (2002) Estudo etnobotânico de plantas medicinais utilizadas em comunidades indígenas no estado do Maranhão, Brasil. Visão Acadêmica 3: 7-12.

Crepaldi MOS \& Peixoto AL (2010) Use and knowledge of plants by "Quilombolas" as subsidies for conservation efforts in an área of Atlantic Forest in Espírito Santo state, Brazil. Biodiversity and Conservation 19: 37-60.

Cruz MP, Reroni N \& Albuquerque UP (2013) Knowledge, use and management of native wild edible plants from a seasonal dry forest (NE, Brazil). Journal of Ethnobiology and Ethnomedicine 9: 2-10.

Cruz MP, Medeiros PM, Sarmiento-Combariza I, Peroni N \& Albuquerque UP (2014) "I eat the manofê so it is not forgotten": local perceptions and consumption of native wild edible plants from seasonal dry forests in Brazil. Journal of Ethnobiology and Ethnomedicine 10: 1-11.

Cunha LVFC \& Albuquerque UP (2006) Quantitative ethnobotany in an Atlantic Forest fragment of Northeastern Brazil implications to conservation. Environmental Monitoring Assessment 114: 1-25.

Cunha-Lima ST et al. (2008) Levantamento da flora medicinal usada no tratamento de doenças metabólicas em Salvador, BA, Brasil. Revista Brasileira de Plantas Medicinais 10: 83-9.

Cunha-Lima ST, Rodrigues ED, Alves C, Merrigan TL, Melo T, Guedes MLS, Nascimento AF \& Toralles MB (2012) The use of medicinal plants by an indigenous Pataxó community in NE Brazil. Revista Brasileira de Plantas Medicinais 14: 84-91.

Cunha-Silva SL, Gualberto SA, Macedo GEL, Silveira TC \& Silva DC (2012) Plantas medicinais usadas pela comunidade do povoado de Laços (Tanhaçú/ Bahia) e encontradas na Floresta Nacional Contendas do Sincorá. Revista Caatinga 25: 130-136.

De Luca VD, Nicolau VR, Gonçalves TM, HarterMarques B, Citadini-Zanette V \& Amaral PA(2014) Utilização de plantas medicinais no entorno do Parque Estadual da Serra Furada, Santa Catarina, Brasil: uma abordagem etnobotânica. Revista Brasileira de Biociências 12: 59-65.

Diegues ACS \& Arruda RSV (2001) Saberes tradicionais e biodiversidade no Brasil. Ministério do Meio Ambiente/USP, Brasília/São Paulo. 176p.

Di Stasi LC, Oliveira GP, Carvalhaes MA, QueirozJunior M, Tien OS, Kakinami SH \& Reis MS (2002) Medicinal plants popularly used in the Brazilian Tropical Atlantic Forest. Fitoterapia 73: 69-91.

Dorigoni PA, Ghedini PC, Fróes LF, Baptista KC, Ethur ABM, Baldisserotto B, Bürger ME, Almeida CE, Lopes AMV \& Záchia RA (2001) Levantamento de dados sobre plantas medicinais de uso popular no município de São João do Polêsine, RS - relação entre enfermidades e espécies utilizadas. Revista Brasileira de Plantas Medicinais 4: 69-79.

Eichemberg MT, Amorozo MCM \& Moura LC (2009) Species composition and plant use in old urban homegardens in Rio Claro, Southeast of Brasil. Acta Botanica Brasilica 23: 1057-1057.

Eichemberg MT \& Amorozo MCM (2013) Contributions of the old urban homegardens for food production 
and consumption in Rio Claro, Southeastern Brazil. Boletim do Museu Paraense Emílio Goeldi, Ciências Humanas 8: 745-755.

Ellis EC, Antill EC \& Kreft H (2012) All is not loss: plant biodiversity in the anthropocene. Plos One 7: 1-9.

Ellis EC (2015) Ecology in an anthropogenic biosphere. Ecological Monographs 85: 287-331.

Falcão DQ, Costa ER, Menezes FS \& Kuster RM (2006) Ethnopharmacological study of plants used topically by the community of Macabú (RJ) and its essential oil chemistry evaluation. Revista Brasileira de Plantas Medicinais 8: 172-174.

Feijó EVRS, Pereira AS, Souza LR, Silva LAM \& Costa LCB (2013) Levantamento preliminar sobre plantas medicinais utilizadas no bairro Salobrinho no município de Ilhéus, Bahia. Revista Brasileira de Plantas Medicinais 15: 595-604.

Fernandes JM, Garcia FCP, Amorozo MCM, Siqueira LC, Marotta COM \& Cardoso IM (2014) Etnobotânica de Leguminosae entre agricultores agroecológicos na Floresta Atlântica, Araponga, Minas Gerais, Brasil. Rodriguésia 65: 539-554.

Ferraz JSF, Ferreira RLC, Santos MVF \& Meunier IMJ (2012) Uses of the woody species of the caatinga in Floresta, Pernambuco, Brazil: indigenous knowledge in the Village Travessão do Ouro. Bosque 33: 183-190.

Ferreira-Junior WSF, Ladio AH \& Albuquerque UPA (2011) Resilience and adaptation in the use of medicinal plants with suspected anti-inflammatory activity in the Brazilian Northeast. Journal of Ethnopharmacology 138: 238-252.

Figueiredo GM, Leitão-Filho HF \& Begossi A (1997) Ethnobotany of Atlantic Forest coastal communities: II. Diversity of plant uses at Sepetiba bay (SE Brazil). Human Ecology 25: 353-360.

Florentino ATN, Araújo EL \& Albuquerque UP (2007) Contribuição de quintais agroflorestais na conservação de plantas da Caatinga, município de Caruaru, PE, Brasil. Acta Botanica Brasilica 21: 37-47.

Fonseca-Kruel VS \& Peixoto AL (2004) Etnobotânica na Reserva Extrativista Marinha de Arraial do Cabo, RJ, Brasil. Acta Botanica Brasilica 18: 177-190.

Fonseca-Kruel VS, Araujo DS, Sá CF \& Peixoto AL (2009) Quantitative ethnobotany of a restinga forest fragment in Rio de Janeiro, Brazil. Rodriguesia 60: 187-202.

Freitas AVL, Coelho MFB, Maia SSS \& Azevedo AB (2012) Plantas medicinais: um estudo etnobotânico nos quintais do Sítio Cruz, São Miguel, Rio Grande do Norte, Brasil. Revista Brasileira de Biociências 10: $48-59$.

Freitas TA \& Rodrigues ACC (2006) Etnobotânica das plantas medicinais de Madre de Deus, Bahia. Sitientibus Série Ciências Biológicas 6: 133-137.

Fuck SB, Athanázio JC, Lima CB \& Ming LC (2005) Plantas medicinais utilizadas na medicina popular por moradores da área urbana de Bandeirantes, PR, Brasil. Semina: Ciências Agrárias 26: 291-296.

Furlanetto PNC, Novakowski GC \& Correa EA(2012) Folk medicine in Mandaguaçu municipality, Paraná State: an ethnobotanical approach. Acta Scient 34: 463-471.

Gandolfo EF \& Hanazaki N (2011) Etnobotânica e urbanização: conhecimento e utilização de plantas de restinga pela comunidade nativa do distrito do Campeche (Florianópolis, SC). Acta Botanica Brasilica 25: 168-177.

Gandolfo EF \& Hanazaki N (2014) Distribution of local plant knowledge in a recently urbanized area (Campeche District, Florianópolis, Brazil). Urban Ecosystems 17: 775-785.

Garcia D, Domingues MV \& Rodriguez E (2010) Ethnopharmacological survey among migrants living in the Southeast Atlantic Forest of Diadema, São Paulo, Brazil. Journal of Ethnobiology and Ethnomedicine 6: 1-19.

Gazzaneo LR, Lucena RFP \& Albuquerque UP (2005) Knowledge and use of medicinal plants by local specialists in a region of Atlantic Forest in the state of Pernambuco (Northeastern Brazil). Journal of Ethnobiology and Ethnomedicine 1: 1-8.

Ghedini PC, Dorigoni PA, Almeida CE, Ethur ABM, Lopes AMV \& Zachia RA (2002) Levantamento de dados sobre plantas medicinais de uso popular no município de São João do Polesine, RS. II - Emprego de preparações caseiras de uso medicinal. Revista Brasileira de Plantas Medicinais 5: 46-55.

Giraldi M \& Hanazaki N (2010) Uso e conhecimento tradicional de plantas medicinais no Sertão do Ribeirão, Florianópolis, SC, Brasil. Acta Botanica Brasileira 24: 395-406.

Giraldi M \& Hanazaki N (2014) (2014) Use of cultivated and harvested edible plants by Caiçaras - what can ethnobotany add to food security discussions? Human Ecology Review 20: 51-73.

Giullietti AM, Neta ALB, Castro AAJF, Gamarrarojas CFL, Sampaio EVSB, Virgínio JF, Queiroz LP, Figueiredo MA, Rodal MJN, Barbosa MRV \& Harley RM (2004) Diagnóstico da vegetação nativa do bioma Caatinga. In: Ministério do Meio Ambiente. Biodiversidade da Caatinga: área e ações prioritárias para a conservação. Ministério do Meio Ambiente, Brasília. Pp. 47-90.

Gomes TB \& Bandeira PSF (2012) Uso e diversidade de plantas medicinais em uma comunidade quilombola no Raso da Catarina, Bahia. Acta Botanica Brasilica 26: 796-809.

Guarim-Neto G \& Morais RG (2003) Recursos medicinais de espécies do Cerrado de Mato Grosso: Um estudo bibliográfico. Acta Botanica Brasilica 17: 561-584.

Guerra AMN, Pessoa MF, Souza CSM \& Maracajá PB (2010) Utilização de plantas medicinais pela comunidade rural Moacir Lucena, Apodi, RN. Bioscience Journal 26: 442-450. 
Guerra NM, Ribeiro JES, Carvalho TKN, Pedrosa KM, Felix LP \& Lucena RFP (2012) Usos locais de espécies vegetais nativas em uma comunidade rural no semiárido nordestino (São Mamede, Paraíba, Brasil). Revista de Biologia e Farmácia, Vol. especial: 184-210.

Hanazaki N, Leitão-Filho HF \& Begossi A (1996) Uso de recursos na Mata Atlântica: o caso da Ponta do Almada (Ubatuba, Brasil). Interciência 21: 268-276.

Hanazaki N, Tamashiro JY, Leitão-Filho HF \& Begossi A (2000) Diversity of plant uses in two Caiçara communities from the Atlantic Forest coast, Brazil. Biodiversity and Conservation 9: 597-615.

Haverroth M (2010) Os desafios da pesquisa etnobotânica entre povos indígenas. In: Silva VA, Almeida ALS \& Albuquerque UP (eds.) Etnobiologia e etnoecologia. Pessoas \& natureza na América Latina. Nupeea, Recife. Pp. 133-141.

IBGE - Instituto Brasileiro de Geografia e Estatística (2010). Sinopse do censo demográfico (2010). Available at <http:/www.censo2010.ibge.gov.br/ sinopse/index.php?dados $=11 \& u f=00>$. Access on 27 August 2012.

IBGE - Instituto Brasileiro de Geografia e Estatística (2012) IBGE lança o mapa de biomas do Brasil e o mapa de vegetação do Brasil, em comemoração ao dia mundial da biodiversidade. Available at $<$ http://www.ibge. gov.br/home/presidencia/noticias/noticia_visualiza. php?id_noticia=169>. Access on 27 August 2012.

Kumagai LS \& N Hanazaki (2013) Contributions of ethnobotany and ethnoecology of Butia catarinensis Noblick \& Lorenzi for the conservation of an endangered area in southern Brazil. Acta Botanica Brasilica 27: 13-20.

Leite AP, Pedrosa KM, Lucena CM, Carvalho TKN, Felix LP \& Lucena RFP (2012) Uso e conhecimento de espécies vegetais úteis em uma comunidade rural no Vale do Piancó (Paraíba, Nordeste, Brasil). Revista de Biologia e Farmácia, vol. especial: 133-157

Leite IA \& Marinho MGV (2014) Levantamento etnobotânico de plantas medicinais em comunidade indígena no município de Baía da Traição, PB. Biodiversidade 13: 82-105.

Liporacci SNL, Miranda TM, Hanazaki N \& Peroni N (2015) How are legal matters related to the access of traditional knowledge being considered in the scope of ethnobotany publications in Brazil? Acta Botanica Brasilica 29: 251-261.

Lisboa MS, Ferreira SM \& Silva MS U (2006) Uso de plantas medicinais para tratar úlceras e gastrites pela comunidade do povoado Vila Capim, município de Arapiraca-AL, nordeste do Brasil. Sitientibus Série Ciências Biológicas 6: 13-20.

Lopes IS, Silva JER, Machado IA, Silva CEM, Marinhos MGV \& Rangel AF (2012) Levantamento de plantas medicinais utilizadas na cidade de Itapetim, Pernambuco, Brasil. Revista de Biologia e Farmácia 7: 115-121.
Lopes LCM \& Lobão AQ (2014) Etnobotânica em uma comunidade de pescadores artesanais no litoral norte do Espírito Santo, Brasil. Boletim do Museu de Biologia Mello Leitão (n. sér.) 32: 29-52.

Lucena RFP, Albuquerque UP, Monteiro JM, Almeida CFCBR, Florentino ATN \& Ferraz JSF (2007) Useful plants of the semi-arid northeastern region of Brazil - a look at their conservation and sustainable use. Environmental Monitoring and Assessment 125: 281-190.

Lucena RFP, Nascimeno VT, Araújo EL \& Albuquerque UP (2008) Local uses of native plants in an area of Caatinga vegetation (Pernambuco, NE-Brazil). Ethnobotany Research Application 6: 3-13.

Lucena CM, Costa GM, Souza RF, Carvalho TKN, Marreiros NA, Alves CAB, Perreira DD \& Lucena RFP (2012a) Conhecimento local sobre cactáceas em comunidades rurais na mesorregião do sertão da Paraíba (Nordeste, Brasil). Revista Biotemas 25: 281-291.

Lucena CM, Costa GGSC, Carvalho TKN, Guerra NM, Quirino ZGM \& Lucena RFP (2012b) Uso e conhecimento de cactáceas no município de São Mamede (Paraíba, Nordeste do Brasil). Revista de Biologia e Farmácia, vol. especial: 121-134.

Lucena RFP, Leite AP, Pedrosa KM, Lucena CM, Vasconcelos-Neto AV \& Ribeiro JPO (2012c) O uso de espécies vegetais no vale do Piancó pode ser explicado por sua disponibilidade local? Revista de Biologia e Farmácia (vol. especial): 55-71.

Lucena RFP, Lucena CM, Araújo EL, Alves AGC \& Albuquerque UP (2013a) Conservation priorities of useful plants from different techniques of collection and analysis of ethnobotanical data. Anais da Academia Brasileira de Ciências 85: 169-186.

Lucena CM et al. (2013b) Use and knowledge of Cactaceae in Northeastern Brazil. Journal of Ethnobiology and Ethnomedicine 9: 1-11.

Macedo AF, Oshiiwa M \& Guarido CF (2007) Ocorrência do uso de plantas medicinais por moradores de um bairro do município de Marília, SP. Revista de Ciências Farmacêutica Básica e Aplicada 28: 123-128.

Maia EA, Francisco J, Pires T \& Manfredi-Coimbra S (2011) O uso de espécies vegetais para fins medicinais por duas comunidades da Serra Catarinense, Santa Catarina, Brasil. Revista de Biologia e Ciência da Terra 11: 54-74.

Marchese JA, Ming L, Franceschi L, Camochena RC, Gomes DRG, Paladini MV, Capelin D \& Marchese CF (2009) Medicinal plants used by "Passo da Ilha" rural community in the city of Pato Branco, southern Brazil. Anais da Academia Brasileira de Ciências 81: 691-700.

Marinho MGV, Silva CC \& Andrade LHC (2011) Levantamento etnobotânico de plantas medicinais em área de caatinga no município de São José de Espinharas, Paraíba, Brasil. Revista Brasileira de Plantas Medicinais 13: 170-182. 
Marodin SM \& Baptista LRM (2001) O uso de plantas com fins medicinais no município de Dom Pedro de Alcântara, Rio Grande do Sul, Brasil. Revista Brasileira de Plantas Medicinais 4: 57-68.

Marodin SM, Silva M \& Baptista LRM (2002) Plantas medicinais do município de Dom Pedro de Alcântra, estado do Rio Grande do Sul, Brasil: espécies, famílias e usos em três grupos da população humana. Revista Brasileira de Plantas Medicinais 5: $1-9$.

Martins LGS, Senna-Valle L \& Pereira NA (2005) Princípios ativos e atividades farmacológicas de 8 plantas popularmente conhecidas por nome de medicamentos comerciais. Revista Brasileira de Plantas Medicinais 7: 73-76.

Meyer L, Quadros KE \& Zeni ALB (2012) Etnobotânica na comunidade de Santa Bárbara, Ascurra, Santa Catarina, Brasil. Revista Brasileira de Biociências 10: 258-266.

Medeiros MFT, Fonseca VS \& Andreata RHP (2004) Plantas medicinais e seus usos pelos sitiantes da Reserva Rio das Pedras, Mangaratiba, RJ, Brasil. Acta Botanica Brasilica 18: 391-399.

Medeiros PM, Ladio AH \& Albuquerque UP (2013a) Patterns of medicinal plant use by inhabitants of Brazilian urban and rural áreas: a macroscale investigation based on available literature. Journal of ethnopharmacology 150: 729-746.

Medeiros PM, Ladio AH, Santos AMM \& Albuquerque UP (2013b) Does the selection of medicinal plants by Brazilian local populations suffer taxonomic influence? Journal of Ethnopharmacology 146: $842-852$

Melo S, Lacerda VD \& Hanazaki N (2008) Espécies de Restinga conhecidas pela comunidade do Pântano do Sul, Florianópolis, Santa Catarina, Brasil. Rodriguésia 59: 799-812.

Mendonça MAD, Correia MS, Santos MIS, Mateus FPS \& Soyinka M (2010) Utilização de plantas medicinais no povoado taiçoca de fora em Nossa Senhora do Socorro, Sergipe, Brasil. Sitientibus Série Ciências Biológicas 10: 252-257.

Merétika AHC, Peroni N \& Hanazaki N (2010) Local knowledge of medicinal plants in three artisanal fishing communities (Itapoá, Southern Brazil), according to gender, age, and urbanization. Acta Botanica Brasilica 24: 386-394.

Metzeger JP (2009) Conservation issues in the Brazilian Atlantic forest. Biology and Conservation, Editorial 142: 1138-1140.

Milanesi LS, Peroni N \& Reis MS (2013) Use of the palm Euterpe edulis martius in landscape units managed by migrants of German origin in Southern Brazil. Journal of Ethnobiology and Ethnomedicine 9: 2-11.

Ministério do Meio Ambiente (2010) Patrimônio nacional dos brasileiros. Secretaria de Biodiversidade e Florestas, Núcleo Mata Atlântica e Pampa, Brasília. 408p.
Ministério do Meio Ambiente (2011) Plano de manejo. Vol. 1. Reserva Biológica da Serra Negra, Brasília. Pp. 1-48.

Ministério do Meio Ambiente (2012) Instituto Chico Mendes. Caatinga. Available at <http://www.mma. gov.br/biomas/caatinga. Access on 25 August 2012.

Miranda TM \& Hanazaki N (2008) Conhecimento e uso de recursos vegetais de restinga por comunidades das ilhas do Cardoso (SP) e de Santa Catarina (SC), Brasil. Acta Botanica Brasilica 22: 203-205.

Miranda TM, Hanazaki N, Govone JS \& Alves DMM (2011) Existe utilização efetiva dos recursos vegetais conhecidos em comunidades caiçaras da Ilha do Cardoso, estado de São Paulo, Brasil? Rodriguésia 62: 153-169

Miranda GS, Souza SR, Amaro MOF, Rosa MB \& Carvalho CA (2013) Avaliação do conhecimento etnofarmacológico da população de Teixeiras, MG, Brasil. Revista de Ciências Farmaceuticas Básica e Aplicada 34: 559-563.

Morais SM, Dantas JDP, Silva ARANAD \& Magalhães EF (2005) Plantas medicinais usadas pelos índios Tapebas do Ceará. Revista Brasileira de Farmacognosia 15: 169-177.

Molares S \& Ladio AH (2009) Ethnobotanical review of the Medicinal Mapuche Flora: use patterns on a regional scale. Journal of Ethnopharmacology 122: 251-260.

Moreira RCT, Costa LCB, Costa RCS \& Rocha EA(2002) Abordagem etnobotânica acerca do uso de plantas medicinais na Vila Cachoeira, Ilhéus, Bahia, Brasil. Acta Farmaceutica Bonaerense 21: 205-211.

Mota R \& Dias HM (2012) Quilombolas e recursos florestais medicinais no sul da Bahia, Brasil. Interações 13: 151-159.

Nascimento VT, Vasconcelos MAS, Maciel MIS \& Albuquerque UPA (2012) Famine foods of Brazil's Seasonal Dry Forests: ethnobotanical and nutritional aspects. Economic Botany 66: 22-34.

Nascimento VT, Lucena RFP, Maciel MIS \& Albuquerque UP (2013) Knowledge and use of wild food plants in areas of Dry Seasonal Forest in Brazil. Ecology of food and Nutrition 52: 1-26.

Negrelle RRB \& Fornazzari KRC (2007) Estudo etnobotânico em duas comunidades rurais (Limeira e Ribeirão Grande) de Guaratuba (Paraná, Brasil). Revista Brasileira de Plantas Medicinais 9: 36-54.

Negrelle RRB, Tomazzoni MI, Ceccon MF \& Valente TP (2007) Estudo etnobotânico junto à Unidade Saúde da Família Nossa Senhora dos Navegantes: subsídios para o estabelecimento de programa de fitoterápicos na Rede Básica de Saúde do município de Cascavel (Paraná). Revista Brasileira de Plantas Medicinais 9: 6-22.

Neto FRG, Almeida GSSA, Jesus NG \& Fonseca MR (2014) Estudo etnobotânico de plantas medicinais utilizadas pela Comunidade do Sisal no município de Catu, Bahia, Brasil. Revista Brasileira de Plantas Medicinais 16: 856-865. 
Oliveira RLC, Lins-Neto EMF, Araujo EL \& Albuquerque UP (2007) Conservation priorities and population structure of woody medicinal plants in an area of caatinga vegetation (Pernambuco State, NE Brazil). Environmental Monitoring and Assessment 132: 189-206.

Oliveira ECS \& Trovão DMBM (2009) O uso de plantas em rituais de rezas e benzeduras: um olhar sobre esta prática no estado da Paraíba. Revista Brasileira de Biociências 7: 245-251.

Oliveira FC, Albuquerque UP, Fonseca-Kruel VS \& Hanazaki N (2009) Avanços nas pesquisas etnobotânicas no Brasil. Acta Botanica Brasilica 23: 590-605.

Oliveira FCS, Barros RFM \& Moitaneto JM (2010a) Plantas medicinais utilizadas em comunidades rurais de Oeiras, semiárido piauiense. Revista Brasileira de Plantas Medicinais 12: 282-301.

Oliveira HB, Kffuri CW \& Casali VWD (2010b) Ethnopharmacological study of medicinal plants used in Rosário da Limeira, Minas Gerais, Brazil. Revista Brasileira de Farmacognosia 20: 256-260.

Oliveira GL, Oliveira AFM \& Andrade LHC (2010c) Plantas medicinais utilizadas na comunidade urbana de Muribeca, Nordeste do Brasil. Acta Botanica Brasilica 24: 571-577.

Oliveira ER \& Menini-Neto L (2012) Levantamento etnobotânico de plantas medicinais utilizadas pelos moradores do povoado de Manejo, Lima Duarte, MG. Revista Brasileira de Plantas Medicinais 14: 311-320.

Paulino RC, Henrique GPSA, Moura ONS, Coelho MFB \& Azevedo RAB (2012) Medicinal plants at the Sítio do Gois, Apodi, Rio Grande do Norte State, Brazil. Revista Brasileira de Farmacognosia 22: 29-39.

Pedrollo CT \& Kinupp VF (2015) Sustainability or Colonialism? Legislative obstacles to research and development of natural products and patents on traditional knowledge in Brazil. Acta Botanica Brasilica 29: 452-456.

Pereira CO, Lima EO, Oliveira RAG, Toledo MS, Azevedo AKA, Guerra MF \& Pereira RC (2005a) Abordagem etnobotânica de plantas medicinais utilizadas em dermatologia na cidade de João Pessoa, Paraíba, Brasil. Revista Brasileira de Plantas Medicinais 7: 9-17.

Pereira RC, Oliveira MTR \& Lemos GCS (2005b) Plantas utilizadas como medicinais no município de Campos de Goytacazes, RJ. Revista Brasileira de Farmacognosia 14: 37-40.

Pereira AJ, Zeni ALB \& Esemann-Quadros K (2011) Estudo etnobotânico de espécies medicinais em Gaspar Alto Central, SC. Revista Científica Eletrônica de Engenharia Florestal 18: 35-52.

Pereira-Junior LR, Andrade AP, Araujo KD, Barbosa AS \& Barbosa FM (2014) Espécies da Caatinga como alternativa para o desenvolvimento de novos fitofarmacos. Floresta e Ambiente 21: 509-520.
Pilla MAC \& Amorozo MCM (2009) O conhecimento sobre os recursos vegetais alimentares em bairros rurais no Vale do Paraíba, SP, Brasil. Acta Botanica Brasilica 23: 1190-1201.

Pinto EPP, Amorozo MCM \& Furlan A (2006) Conhecimento popular sobre plantas medicinais em comunidades rurais de mata atlântica - Itacaré, BA, Brasil. Acta Botanica Brasilica 20: 751-762.

Pires MV, Abreu PP, Soares CS, Souza B, Mariano D, Silva DC \& Rocha EA (2009) Etnobotânica de terreiros de candomblé nos municípios de Ilhéus e Itabuna, Bahia, Brasil. Revista Brasileira de Biociências 7: 3-8.

Poderoso AR, Hanazaki N \& Dunaiski AJ (2012) How is local knowledge about plants distributed among residents near a protected area? Ethnobiology and Conservation 1: 1-8.

Pulido MT, Pagaza-Calderón EM, Martinez-Ballesté, Maldonado-Almanza B, Saynes A \& Pacheco RM (2008) Home gardens as an alternative for sustainability: challenges and perspectives in Latin America. Research Signpost 2: 1-25.

Ribeiro DA, Macêdo DG, Oliveira LGS, Saraiva ME, Oliveira SF, Souza MMA \& Menezes IRA (2014a) Potencial terapêutico e uso de plantas medicinais em uma área de Caatinga no estado do Ceará, nordeste do Brasil. Revista Brasileira de Plantas Medicinais 16: 912-930.

Ribeiro JPO, Carvalho TKN, Ribeiro JES, Souzas RF, Lima JRF, Oliveira RS, Alves CAB, Jardim JG \& Lucena RFP (2014b) Can ecological apparency explain the use of plant species in the semi-arid depression of Northeastern Brazil? Acta Botanica Brasilica 28: 476-483.

Ritter MR, Sobierajski GR, Schenkel EP \& Ment LA (2002) Plantas usadas como medicinais no município de Ipê, RS, Brasil. Revista Brasileira de Farmacognosia 12: 51-62.

Ritter MR, Silva TC, Araújo EL \& Albuquerque UP(2015) Bibliometric analysis of ethnobotanical research in Brazil (1988-2013). Acta Botanica Brasilica 29: 113-119.

Rodrigues AP \& Andrade LHC (2014) Levantamento etnobotânico das plantas medicinais utilizadas pela comunidade de Inhamã, Pernambuco, Nordeste do Brasil. Revista Brasileira de Plantas Medicinais 16: 721-730.

Rodrigues ACC \& Guedes MLS (2006) Utilização de plantas medicinais no Povoado Sapucaia, Cruz das Almas, Bahia. Revista Brasileira de Plantas Medicinais 8:1-7.

Rodrigues LC, Silva AA, Silva RB, Oliveira AFM \& Andrade HC (2013) Conhecimento e uso da Carnaúba e da Algaroba em comunidades do sertão do Rio Grande do Norte, Nordeste do Brasil. Revista Árvore 37: 451-457.

Roque AA, Rocha RM \& Loiola MIB (2010) Uso e diversidade de plantas medicinais da Caatinga na comunidade rural de Laginhas, município de Caicó, 
Rio Grande do Norte (nordeste do Brasil). Revista Brasileira de Plantas Medicinais 12: 31-42.

Roque AA \& Loiola MIB (2013) Potencial de uso dos recursos vegetais em uma comunidade rural no Semiárido Potiguar. Revista Caatinga 26: 88-98.

Rossato SC, Leitão-Filho HF \& Begossi A (1999) Ethnobotany of caiçaras of the atlantic forest coast (Brazil). Economic Botany 53: 387-395.

Rufino MUL, Costa JTM, Silva VAS \& Andrade LHC (2008) Conhecimento e uso do ouricuri (Syagrus coronata) e do babaçu (Orbignya phalerata) em Buíque, PE, Brasil. Acta Botanica Brasilica 22: 1141-1149.

Santos JFL, Amorozo MCM \& Ming LC (2008) Uso popular de plantas medicinais na comunidade rural da Vargem Grande, município de Natividade da Serra, SP. Revista Brasileira de Plantas Medicinais 10: 67-81.

Santos JP, Araujo EL \& Albuquerque UP (2008) Richness and distribution of useful woody plants in the semiarid region of northeastern Brazil. Journal of Arid Environments 72: 652- 663.

Santos KL, Peroni N, Guries RP \& Nodari RO (2009a) Traditional knowledge and management of Feijoa (Acca sellowiana) in Southern Brazil. Economic Botany 63: 204-214.

Santos LL, Ramos MA, Silva SI, Sales MF \& Albuquerque UP (2009b) Caatinga ethnobotany: anthropogenic landscape modification and useful species in Brazil's Semi-Arid Northeast. Economic Botany 63: 363-374.

Santos SLDX, Alves RRN \& Santos SLDX (2012) Plantas utilizadas como medicinais em uma comunidade rural do semi-árido da Paraíba, Nordeste do Brasil. Revista Brasileira de Farmácia 93: 68-79.

Santos AS, Oliveira LCL, Curado FF \& Amorim LO (2013) Caracterização e desenvolvimento de quintais produtivos agroecológicos na comunidade Mem de Sá, Itaporanga d'Ajuda-Sergipe. Revista Brasileira de Agroecologia 8: 100-111.

Santos LL, Nascimento ALB, Vieira FJ, Silva VA, Voeks R \& Albuquerque UP (2014) The cultural value of invasive species: a case study from Semi-Arid Northeastern Brazil. Economic Botany 68: 283-300.

Silva-Almeida MF \& Amoroso MCM (1998) Medicina popular no distrito de Ferraz, município de Rio Claro, estado de São Paulo. Revista Brasiliera de Ecologia 2: 36-46.

Silva ACO \& Albuquerque UP (2005) Wood medicinal plants of the Caatinga in the state of Pernambuco (northeast Brazil). Acta Botanica Brasilica 19: 17-26.

Silva AJR \& Andrade LHC (2005) Etnobotânica nordestina: estudo comparativo da relação entre comunidades e vegetação na Zona do Litoral - Mata do estado de Pernambuco, Brasil. Acta Botanica Brasilica 19: 45-60.
Silva AJR \& Andrade LHC (2006) Cultural significance of plants in communities located in the coastal forest zone of the state of Pernambuco, Brazil. Human Ecology 34: 447-465.

Silva JA \& Bündchen M (2011) Conhecimento etnobotânico sobre as plantas medicinais utilizadas pela comunidade do Bairro Cidade Alta, município de Videira, Santa Catarina, Brasil. Unoesc \& Ciência - ACBS 2: 129-140.

Silva TS \& Freire EMX (2010) Abordagem etnobotânica sobre plantas medicinais citadas por populações do entorno de uma unidade de conservação da caatinga do Rio Grande do Norte, Brasil. Revista Brasileira de Plantas Medicinais 12: 427-435.

Silva FG \& Oliveira GL (2013) Conhecimento popular e atividade antimicrobiana de Cydonia oblonga Miller (Rosaceae). Revista Brasileira de Plantas Medicinais 15: 98-103.

Silva GLC, Gaertner P, Marson PG, Schwarz EA \& Santos CAN (2004) An ethno-pharmacobotanical survey in Salto Caxias hydroelectric power plant in Paraná state, Brazil, before the flooding. Acta Farmaceutica Bonaerense 23: 148-153.

Silva MS, Antoniolli AR, Batista JS \& Mota CN (2006) Plantas medicinais usadas nos distúrbios do trato gastrointestinal no povoado Colônia Treze, Lagarto, SE, Brasil. Acta Botanica Brasilica 20: 815-829.

Silva MD, Dreveck S \& Zeni ALB (2009) Estudo etnobotânico de plantas medicinais utilizadas pela população rural no entorno do Parque Nacional da Serra do Itajaí - Indaial. Revista Saúde e Ambiente 10: $54-64$.

Silva FS, Ramos MA, Hanazaki N \& Albuquerque UP (2011) Dynamics of tradicional knowledge of medicinal plants in a rural community in the Brazilian semi-arid region. Revista Brasileira de Farmacognosia 21: 382-391.

Silva WA, Fagundes NCA, Coutinho CA, Soares ACM, Campos PV \& Figueiredo LS (2012a) Levantamento etnobotânico de plantas medicinais na cidade de São João da Ponte, MG. Revista de Biologia e Farmácia 7: 122-131.

Silva NCB, Regis ACD, Esquibel MA, Santos JES \& Almeida MZ (2012b) Uso de plantas medicinais na comunidade quilombola da Barra II, Bahia, Brasil. Boletim Latinoamerica y del Caribe de Plantas Medicinais y Aromáticas 11: 435-453.

Silva NCB, Regis ACD \& Almeida MZ (2012c) Estudo etnobotânico em comunidades remanescentes de quilombo em Rio de Contas, Chapada Diamantina, Bahia. Revista Fitos 7: 99-109.

Silva HCH, Caraciolo RLF, Marangon LC, Ramos MA, Santos LL \& Albuquerque UP (2014a) Evaluating different methods used in ethnobotanical and ecological studies to record plant biodiversity. Journal of Ethnobiology and Ethnomedicine 10: 2-11. 
Silva FS, Albuquerque UP, Costa-Júnior LM, Lima AS, Nascimento ALB \& Monteiro JM (2014b) An ethnopharmacological assessment of the use of plants against parasitic diseases in humans and animals. Journal of Ethnopharmacology 155: 1332-1341.

Silva N, Lucena RFP, Lima JRF, Lima GDS, Carvalho TKN, Souza-Júnior SP \& Alves CAB (2014c) Conhecimento e uso da vegetação nativa da Caatinga em uma comunidade rural da Paraíba, Nordeste do Brasil. Boletim do Museu de Biologia Mello Leitão 34: 5-37.

Soarez ELC, Vendruscolo GS, Eisinger S \& Záchia RA (2004) Estudo etnobotânico do uso dos recursos vegetais em São João do Polêsine, RS, Brasil, no período de outubro de 1999 a junho de 2001. I origem e fluxo do conhecimento. Revista Brasileira de Plantas Medicinais 6: 69-95.

Sobrinho FAP et al. (2011) Uso de plantas medicinais no entorno da Reserva Biológica de Tinguá, Nova Iguaçu, RJ. Revista Acadêmica: Ciências Agrárias Ambientais 9: 195-206.

Soldati GT, Duque-Brasil R, Silva TC, Coelho FMG \& Albuquerque UP (2011) Conhecimento botânico e representações ambientais em uma comunidade rural no Domínio Atlântico: bases para conservação local. Sitientibus Série Ciências Biológias 11: 265-278.

SOS Mata Atlântica e Instituto Nacional de Pesquisas Espaciais (2015) Atlas dos remanescentes florestais da Mata Atlântica. Desenvolvido por SOS Mata Atlântica e Instituto Nacional de Pesquisas Espaciais. Apresenta a situação dos remanescentes florestais dos municípios que se localizam nas áreas originais da Mata Atlântica. Available at $<$ http://mapas.sosma.org.br/>. Access on 2015.

Souza RKD, Silva MAP, Menezes IRA, Ribeiro DA, Bezerra LR \& Souza MA(2014) Ethnopharmacology of medicinal plants of carrasco, northeastern Brazil. Journal of Ethnopharmacology 157: 99-104.

Strachulski J \& Floriani N (2013) Conhecimento popular sobre plantas: um estudo etnobotânico na comunidade rural de Linha Criciumal, em Cândido de Abreu, PR. Revista Geografar 8: 125-153.

Teixeira AS \& Melo JIM (2006) Plantas medicinais utilizadas no município de Jupi, Pernambuco, Brasil IHERINGIA, Série Botânica 61: 5-11.

Thomaz LD \& Monteiro R (1997) Composição florística da Mata Atlântica de encosta da Estação Biológica de Santa Lúcia, Município de Santa Teresa, ES. Boletim do Museu de Biologia Mello-Leitão 7: 3-48.

Tomazi LB, Aguiar PA, Citadini-Zanette V \& Rossato AE (2014) Estudo etnobotânico das árvores medicinais do Parque Ecológico Municipal José Milanese, Criciúma, Santa Catarina, Brasil. Revista Brasileira de Plantas Medicinais 16: 450-461.

Tôrres DF, Oliveira ES, Alves RRN \& Vasconcellos A (2009) Etnobotânica e etnozoologia em unidades de conservação: uso da biodiversidade na Apa de Genipabu, Rio Grande do Norte, Brasil. Interciencia 34: 623-629.

Trotta J, Messias PA, Pires AHC, Hayashida CT, Camargo CDE \& Futemma C (2012) Análise do conhecimento e uso popular de plantas de quintais urbanos no estado de São Paulo, Brasil. Revista de Estudos Ambientais 14: 17-34.

Tuler AC \& Silva NCB (2014) Women's ethnomedicinal knowledge in the rural community of São José da Figueira, Durandé, Minas Gerais, Brazil. Revista Brasileira de Farmacognosia 24: 159-170.

Vieira RF \& Martins MVM (2000) Recursos genéticos de plantas medicinais do Cerrado: uma compilação de dados. Revista Brasileira de Plantas Medicinais 3: 13-36.

Vigano J, Viganó JA \& Silva CTAC (2007) Utilização de plantas medicinais pela população da região urbana de Três Barras do Paraná. Acta Scientiarum, Health Sciences 29: 27-36.

Zank S \& Hanazaki N (2012) Exploring the links between ethnobotany, local therapeutic practices, and protected areas in Santa Catarina coastline, Brazil. Journal of Evidence-based complementary and alternative medicine 2012: 1-15.

Zeni ALB \& Bosio F (2006) Medicinal plants used in the Nova Russia, Brazilian Atlantic Rain Forest. Revista Brasileira de Plantas Medicinais 8: 167-171.

Zeni ALB \& Bosio F (2011) O uso de plantas medicinais em uma comunidade rural de Mata Atlântica - Nova Rússia, SC. Neotropical Biology Conservation 6: 55-63.

Zuchiwschi E, Fantini AC, Alves AC \& Peroni N (2010) Limitações ao uso de espécies florestais nativas pode contribuir com a erosão do conhecimento ecológico tradicional e local de agricultores familiares. Acta Botanica Brasilica 21: 264-276. 